\title{
Impact of new healthcare legislation and price policy on healthcare services provider at the time of financial crisis. A 10 years study
}

\author{
Ivona Malovecka ${ }^{1}$, Konstantinos Papargyris ${ }^{1}$, Daniela Minarikova ${ }^{1}$, Viliam Foltan ${ }^{1}$, \\ Anezka Jankovska ${ }^{2}$ \\ Department of Organisation and Management in Pharmacy, Faculty of Pharmacy, Comenius University in Bratislava. Bratislava, \\ Slovak Republic \\ 2 Department of Finance, Banking and Investment, Faculty of National Economy, University of Economics in Bratislava. Bratislava, \\ Slovak Republic
}

\begin{abstract}
Monitoring, calculation and assessment of healthcare services prosperity in the community pharmacy with the help of financial analysis indicators for the years 2003-2012, using financial statements was conducted, with respect to profitability, debt, liquidity, working capital, and efficiency parameters. These ratios reflect various changes that hold between years 2003 and 2012. Under the time of financial crisis, recession and serious socio-economic changes the profitability parameter Gross Profit ranged from 2003-2011 $=16.12-22.79 \%$ (average $=19.20 \%$; mean $=19.78 \% ; \sigma=2.41$ ), but in 2012 decreased on $14.35 \%$. Net Profit ranged 2003-2011 $=10.96-18.3 \%$ (average $=14.62 \%$; mean $=16.62 \% ; \sigma=4.92$ ), while in 2012 reached only $2.29 \%$. Debt ratio ranged from 2003-2012 $=2.33-4.81$ (average $=3.44 ;$ mean $=3.07 ; \sigma=0.82$ ). Liquidity parameters Current Ratio spread between 2003-2012 $=1.13-1.71$ (average $=1.43$; mean $=1.46 ; \sigma=0.15)$ and Quick Ratio spread between 2003-2012 $=0.72-1.27$ (average $=1.07$; mean $=1.09 ; \sigma=0.15$ ). Working Capital Ratio ranged from 2003-2012 $=2.66-12.94$ (average $=9.58 ;$ mean $=10.06 ; \sigma=3.1$ ) and efficiency ratios were measured either. All changes that have taken place in the society had an impact on community pharmacy finance by worsening its profitability, liquidity, working capital and some of efficiency parameters. Therefore the stability of community pharmacy may be threatened and may affect its future performance.
\end{abstract}

\section{Keywords}

Community pharmacy; Financial analysis; Corrective measures

\section{INTRODUCTION}

The economic crisis and the requirements for structural changes in all aspects of public health brought a new era of reforms in the country as well as the healthcare system itself. The pharmaceutical legislation, both European and national, were implemented to protect public and state interests. Application of new legislation influenced providers of healthcare services, community pharmacies as well, in different areas. Community pharmacies nowadays, play a crucial role in the health status of a society. They are healthcare units designed to provide pharmaceutical care. They constitute the direct providers of medicines and the basic contributors in the provision of pharmaceutical services to patients [1]. Once financial crisis started to spread worldwide, it was anticipated the affection of more and more countries by this global phenomenon and the expansion of a negative impact on their economic growth and development [2]. Financial crisis, characterized by general economic slowdown, reduced retail growth and decreased profit margins has placed healthcare system into a very difficult position [3]. Also the employees feel the impact of the recent economic crisis on employee workrelated attitudes via changes in regulatory focus [4]. At the present time, community pharmacy is going through very tough moments, since it daily faces financial constraints and
Corresponding author Ivona Malovecka malovecka@fpharm.uniba.sk

\section{Disclosure}

The authors have no conflicts of interest

to declare 
economic pressure [5]. Furthermore, healthcare market has been deregulated in such a way that revenues are diminished for the new participants entering the market. All these effects of financial crisis are creating a considerable financial pressure on community pharmacy which is also daily confronted with accelerated competition [6]. In order to alleviate the problems, generated mainly by financial crisis, the role of the pharmacist is gradually and progressively changing $[7,8]$. Despite the difficult time that it faces, community pharmacy must maintain its operation and survive at the upcoming time [9]. Except of social and medical objectives, there is also the economic objective of a community pharmacy that is focused on the generation of profit. Gaining profit is of great importance not only for the existence of the community pharmacy but also for its further development $[10,11]$. In order to assure its financial stability, a community pharmacy should possess and manage sufficient funds so as to cover its obligations and to normally run the business [12]. During the normal operation of a community pharmacy, in the provision of pharmaceutical care, inputs form the bulk of the costs and outputs the revenues. The difference between costs and revenues is the profit of the community pharmacy. Operating order of the community pharmacy is required so as to ensure its proper operation [13]. The necessary parts that contribute to this proper operation include the existence and careful management of organizational structure of the pharmacy, pharmacy premises, pharmacy stuff and other activities.

Advanced systematic research revealed that there is no evidence in scientific literature that method of financial analysis has been provided in community pharmacy. The principal objective of this work is to describe the methodology of assessing provider of healthcare services and describe the financial performance of healthcare services provided by an independent community pharmacy. Article focuses on total revenue and costs of the community pharmacy's overall operations.

\section{THE FINANCIAL INDICATORS}

Profitability, debt, liquidity, Working Capital and efficiency are parameters that provide significant information of implementing new healthcare legislation and price policy on the "financial health" of the independent community pharmacy. The better the understanding of all parameters, the greater will be the improvement in managing and controlling the services and finances of the independent community pharmacy.

\section{Profitability ratios}

Profitability Ratios (PR) comprises ratios that measure the relative ability of the community pharmacy's business to generate profit. These ratios are of great usefulness in telling whether the community pharmacy's business performance is as profitable as it should be, or not. Concerning their assessment, an increase in the ratios is indicative of a positive trend and a decrease of a negative trend respectively. The profitability ratios intended for the analysis of the profit and loss statement of an enterprise are gross profit margin ratio, net profit margin ratio and break even analysis [14].

\section{Gross Profit Margin Ratio}

The Gross Profit Margin Ratio (GPMR) is an indicator of a company's profitability and it expresses the gross profit as a proportion of sales. It constitutes an indicator depicting the business's financial health and it portrays how efficiently community pharmacy's business uses its materials and labor in order to produce goods or services. Furthermore, gross profit margin ratio gives an indication of the pricing, cost structure and production efficiency of the enterprise. The mathematical formula for the calculation of gross profit margin ratio is:

\section{GPMR = Gross Profit / Income}

Generally, it is valid that the higher the gross profit margin ratio, the better it is for the community pharmacy's business. This is explained by the fact that the higher the ratio, the more the business retains of each euro of sales. Moreover, a high ratio demonstrates that more money is remaining for other operating expenses and net profit. On the other hand, a low gross profit margin ratio gives an indication that the community pharmacy generates a low level of revenue to pay for operating expenses and net profit. Such situation signifies that either the business is unable to control production and inventory costs or that prices have been set too low [15].

\section{Net Profit Margin Ratio}

The Net Profit Margin Ratio (NPMR) is an indicator of business's profitability and expresses the net profit as a proportion of sales. NPMR constitutes an indicator of company's financial health. It shows the proportion of every euro of sales that leftover after all expenses have been paid and remains as net profit. Net profit is essential to pay for interest, taxes and distribution to the owners. The mathematical formula for the calculation of net profit margin ratio is:

$$
\text { NPMR }=\text { Net Profit / Income }
$$


The higher the net profit margin ratio, the better it is for the community pharmacy's business. A high NPMR signifies the effectiveness of a business at converting sales into profit. Moreover, it may mean that community pharmacy is making benefit from some competitive advantage that can provide the enterprise with further capacity and flexibility during through tough and difficult times. A low net profit margin ratio primarily indicates that the community pharmacy is not generating enough sales, the gross profit margin is too low or that community pharmacy is unable to control operating expenses so as to leave an acceptable profit [16].

\section{Debt ratio}

Debt Ratio (DR) comprise solvency ratios that measure the overall ability of the business to pay its legal debt. More specifically, they are attempting to quantify community pharmacy's ability to satisfy long-term debt obligations. Furthermore, they determine the corresponding viability of the company to continue its future operations. The most important solvency indicator is Debt to Equity Ratio (DER). DER is a solvency indicator that relates the use of shareholder's equity to the total liabilities of a company. It signifies the vulnerability of the business to risk and is frequently used by creditors to quantify the ability of the business to repay loans. Moreover, it demonstrates the proportion of capital invested by the business owners to the funds provided by external lenders. The mathematical formula for the calculation of DER is:

\section{DER $=$ Total Liabilities / Owner's Equity}

The higher the DER, the more the business relies on debt to finance its operations and the greater the risk to external lenders. DER of $1: 1$ indicates that the external lenders and the owners are bearing the same degree of risk. Therefore, DER which is lower than 1:1 means that debt is less than owners' equity so the external lenders are bearing less risk than the owners. This situation signifies that the business is positively geared and the owners have a stronger financial interest in the business than external lenders. On the other hand, DER of more than 1:1 means that debt is higher than the owners' equity so the external lenders are bearing more risk than the owners. The business is characterized by a negatively geared status and external lenders have a stronger financial interest in the business than the owners. As a common rule, a DER lying between ranges of $1: 1$ to $4: 1$ is considered acceptable. However, such acceptance depends on individual business and industry circumstances. Generally, a DER of 2:1 is considered to be the recommended value for a community pharmacy and is often used for business loans. In case that business undertakes too much debt, this can put the community pharmacy at risk [17].

\section{Liquidity ratios}

Liquidity Ratios (LR) comprise ratios that measure the community pharmacy's business capacity to meet short term financial commitments as they become due. Liquidity describes the relative ability of the business to convert assets, such as inventory, into cash. For the evaluation of liquidity it should be examined information relating to the amounts, timing and certainty of the community pharmacy's future cash flow. For this purpose, there are used ratios that designate a comparison of the proportions of current assets and short term liabilities. These LR are known as Current Ratio and Quick Ratio.

The Current Ratio (CR) comprises a common benchmark for measuring community pharmacy's business cash flow or liquidity. It constitutes an indicator showing whether the business has sufficient current assets in order to meet its short term financial obligations (current liabilities). The mathematical formula used for the calculation of $\mathrm{CR}$ is:

\section{$\mathrm{CR}=$ Current Assets / Current Liabilities}

The higher the CR, the greater the capacity of the business to meet short term financial commitments. The general guide for most businesses is to keep the CR value above $1: 1$ and as close as possible to the value of $2: 1$. CR of $2: 1$ is considered to be the desirable value for a community pharmacy's business. Too high CR may indicate that the business performs investment in current assets that could otherwise be used for income production. On the other hand, too low CR indicates that there may not be enough current assets so as to meet short term financial commitments when they are due [18].

\section{Quick Ratio (QR)}

Quick Ratio (QR) is another benchmark that measures community pharmacy's short term liquidity. It constitutes an indicator determining the level of all assets that can be easily and quickly convertible into cash so as to be used in meeting short term liabilities. QR provides a better test of a company's short term ability to pay debt than CR, because it excludes inventory. The mathematical formula for the calculation of $\mathrm{QR}$ is:

$$
\begin{gathered}
\mathrm{QR}=(\text { Current Assets - Inventory }) / \\
\text { Current Liabilities }
\end{gathered}
$$


The higher the ratio, the higher the level of liquidity for the organization's business. The ideal QR for a community pharmacy's business is 1:1 or higher, value which signifies that current liabilities can be met from current assets without the need to sell inventory.

\section{Working Capital and Working Capital Ratio}

\section{Working Capital}

Working Capital (WC) describes the amount of money needed for a community pharmacy in order to fund its normal daily operations. Moreover, it makes sure that business has sufficient cash to pay its debts and expenses as they mature, especially during start-up periods. This cycle measures the time lag between paying for goods or medicines supplied and the final receipt of cash from their sale. Therefore, in order to achieve a more effective $\mathrm{WC}$ it is essential for a community pharmacy to keep this cycle as short as possible. The primary elements of the WC cycle are cash, inventory, accounts receivable and accounts payable. A successful cash management is characterized by control of each of the cycle's steps including all transactions from investing in inventories and converting them through sales to receivables, to collecting the receivables, using the cash to pay current debts and then replace the inventory sold. The lower is WC, the better for community pharmacy business. The mathematical formula for WC calculation is:

$$
\begin{gathered}
\text { WC (value } €)=\text { Current Assets - } \\
\text { Current Liabilities }
\end{gathered}
$$

The expression of WC as ratio (current ratio/ liquidity ratio) gives a better measure of liquidity.

WC Ratio $($ WCR $)=[($ Inventory + Accounts

Receivable - Accounts Payable) / Sales] × 100

WCR $(€$ value $)=$ Sales $\times($ WC as a\% of Sales $)$

The higher is the WCR, the more money is needed to fund the sale for the time delay in the WC cycle. Also, it is valid the fact that the higher the WCR, the slower the collection of money from the business. This method comprises a very useful tool for a community pharmacy's business to estimate the amount of extra WC needed if turnover is increased by a certain amount [19].

\section{Efficiency ratios}

Efficiency Ratios (ER) are ratios that measure how well the pharmacy manager is using available capital. They provide a picture of how well the community pharmacy manages its assets through indicating the speed or time needed for the enterprise to convert non-cash assets to cash assets. ER included: Accounts Receivable Turnover Ratio, Average Collection Period, Accounts Payable Turnover Ratio, Average Payment Period and Inventory Turnover Ratio.

\section{Accounts Receivable Turnover Ratio}

Accounts Receivable Turnover Ratio (ARTR) measures the efficiency of the business in collecting credit sales by indicating how quickly credit customers are paying the community pharmacy. It is generally valid that the greater the ARTR during the year, the shorter the time interval between the sale and collecting the cash for that sale. This ratio actually measures the effectiveness of credit management policies with extending credits and collecting debts. The mathematical formula for the calculation of ARTR is:

\section{ARTR $=$ Total Sales $/$ Accounts Receivable}

The higher ratios are desirable since they indicate that the business collects faster its accounts receivable and it consequently has more cash available.

\section{Average Collection Period}

Average Collection Period (ACP) measures the community pharmacy's liquidity on accounts receivable by indicating the average number of days taking the business to collect payment for sales to customers on credit. The mathematical formula for the calculation of $\mathrm{ACP}$ is:

$$
\begin{gathered}
\text { ACP }=365 / \text { (Total Sales } / \\
\text { Accounts Receivable) }=365 / \text { ARTR }
\end{gathered}
$$

The shorter is the period, the better the business collecting payment for sales on customers on credit and it doesn't take the community pharmacy very long time to turn its receivables into cash. This speed of bills collection has a vital impact on the cash flow of the business since it signifies how long the community pharmacy's money is being tied up in customer credit.

\section{Accounts Payable Turnover Ratio}

Accounts Payable Turnover Ratio (APTR) indicates how quickly the community pharmacy pays its bills as well as how often payables turn over during the year. The mathematical formula used for the calculation of APTR is:

$$
\begin{gathered}
\text { APTR }=\text { Cost of Goods Sold / } \\
\text { Accounts Payable }
\end{gathered}
$$


An increasing trend in APTR is desirable since it signifies that the business is paying its suppliers at a faster rate. Furthermore, trends in the APTR show how efficiently the community pharmacy manages its outgoing payments and can help in the assessment of the business's cash status.

\section{Average Payment Period (APP)}

Average Payment Period (APP) is defined as the average number of days it takes the community pharmacy to pay for its credit purchases. The mathematical formula for the calculation of APP is:

$$
\begin{gathered}
\text { APP }=365 / \text { (Cost of Goods Sold / } \\
\text { Accounts Payable) }=365 / \text { APTR }
\end{gathered}
$$

A high number of days indicate that there is a relatively long period for the enterprise between purchasing inventory or materials and paying for them. A longer APP may signify that community pharmacy's business has a problem with cash shortages. A shorter APP designates prompt payments to creditors and reflects the creditworthiness of a company, a very short payment period may indicate that the business is not taking full advantage of the credit terms allowed by suppliers. Therefore, it is generally desirable a relatively high accounts payable payment period since it is indicative of business's good cash management.

\section{Inventory Turnover Ratio (ITR)}

Inventory Turnover Ratio (ITR) expresss the number of times inventory turns over (is used up) during the year. It measures the efficiency of the business in managing and selling its inventory by indicating how quickly inventory is sold and replaced in the operating period. The mathematical formula for the calculation of ITR is:

ITR = Cost of Goods Sold / Annual Average Value of Inventory

\section{Where}

Annual Average Value of Inventory = (Opening Inventory + Closing Inventory) / 2

A high ITR is indicative of high demand for products or services and signifies good inventory management. Nevertheless, a high ITR may designate a shortage of inventory and may also signify that community pharmacy is losing sales because of inadequate stock on hand. In contrast, a low ITR may indicate the presence of too much or obsolete inventory or designate that inventory is naturally slow moving in the industry [20].

\section{METHODOLOGY AND RESEARCH METHODS}

The methodology relies on the calculation, monitoring and assessment of financial indicators which are critical for the financial analysis of the independent community pharmacy business. The analyzed financial characteristics have been properly segmented into profitability, debt, liquidity, working capital and efficiency parameters. For the calculation of these parameters it was imperative the need for information from each annual profit and loss statement as well as from the respective balance sheets. These statements combine thousands of records about costs and revenues undertaken in community pharmacy. Examined data were collected for the period years 2003-2012 from the independent community pharmacy located in Greece. After acquisition, financial data were converted into ratios to provide a complete view of the community pharmacy's business, adjustments for inflation to overcome the shortfalls that may occur in a longer decade analysis. The number of patients/customers visited the community pharmacy can be marked as crucial factor that affects income and turnover of the enterprise [21]. As it is not a part of financial analysis we have to assess it separately. The statistical information of the examined decade was obtained from the accounting office of the enterprise after taking into account all sales and receipts of the business for every single year.

\section{RESULTS AND DISCUSSION}

Main results are summarized in Table I.

\section{Profitability ratios}

\section{GPMR analysis}

From 2010 GPMR has recorded a significant downward trend. Declining trend culminated in 2012 when has been recorded the lowest value of the GPMR in comparison to the whole examined decade $(\min =0.1435 / 14.35 \%$; $\max$ $=0.2279 / 22.79 \%$; average $=0.1920 / 19.20 \%$; mean $=0.1978 / 19.78 \% ; \sigma=2.41)$. Declining trend signifies that community pharmacy generates low level of revenue to pay for its operating expenses and net profit, enterprise is not keeping production and inventory costs under control or that prices have been set too low.

\section{Corrective action in GPMR}

The community pharmacy in order to remain financially viable should decrease cost of goods sold (COGS) and generally develop a better managing and control of COGS, manage and revise pricing either by setting prices higher or even by decreasing possible cash discounts. 


\begin{tabular}{|c|c|c|c|c|c|c|c|c|c|c|c|c|c|c|}
\hline & \multicolumn{10}{|c|}{ Year } & \multirow{2}{*}{ Average } & \multirow{2}{*}{ Max } & \multirow{2}{*}{ Min } & \multirow{2}{*}{ Mean } \\
\hline & 2003 & 2004 & 2005 & 2006 & 2007 & 2008 & 2009 & 2010 & 2011 & 2012 & & & & \\
\hline \multicolumn{15}{|c|}{ Profitability Ratios } \\
\hline GPMR & 0.1891 & 0.1612 & 0.1984 & 0.1940 & 0.1971 & 0.1993 & 0.2006 & 0.2279 & 0.2093 & 0.1435 & 0.1920 & 0.2279 & 0.1435 & 0.1978 \\
\hline NPMR & 0.1536 & 0.1284 & 0.1742 & 0.1650 & 0.1673 & 0.1788 & 0.1796 & 0.1830 & 0.1096 & 0.0229 & 0.1462 & 0.1830 & 0.0229 & 0.1662 \\
\hline \multicolumn{15}{|c|}{ Debt Ratio } \\
\hline DER & 2.9658 & 3.1246 & 4.8094 & 2.9760 & 3.3910 & 4.4171 & 4.4665 & 3.0107 & 2.9560 & 2.3311 & 3.4448 & 4.8094 & 2.3311 & 3.0676 \\
\hline \multicolumn{15}{|c|}{ Liquidity Ratios } \\
\hline CR & 1.4388 & 1.2734 & 1.4010 & 1.7051 & 1.5051 & 1.4911 & 1.4802 & 1.4661 & 1.4452 & 1.1294 & 1.4335 & 1.7051 & 1.1294 & 1.4557 \\
\hline QR & 1.0636 & 0.9173 & 1.1094 & 1.2692 & 1.1208 & 1.1627 & 1.1687 & 1.0727 & 1.0747 & 0.7193 & 1.0678 & 1.2692 & 0.7193 & 1.0921 \\
\hline \multicolumn{15}{|c|}{ Working Capital } \\
\hline WC & 9.5545 & 6.0790 & 11.2085 & 12.9353 & 10.5572 & 12.0972 & 12.2709 & 8.9907 & 9.4248 & 2.6634 & 9.5782 & 12.9353 & 2.6634 & 10.0558 \\
\hline \multicolumn{15}{|c|}{ Efficiency Ratios } \\
\hline ARTR & 4.3178 & 4.9027 & 3.2247 & 4.2943 & 4.2691 & 3.4914 & 3.3484 & 4.8327 & 4.3958 & 6.7539 & 4.3831 & 6.7539 & 3.2247 & 4.3061 \\
\hline ACP & 85 & 74 & 113 & 85 & 85 & 105 & 109 & 76 & 83 & 54 & 87 & 113 & 54 & 85 \\
\hline APTR & 3.7239 & 3.7706 & 2.8677 & 4.3934 & 3.8416 & 3.2504 & 3.1284 & 4.0025 & 3.7355 & 4.1610 & 3.6875 & 4.3934 & 2.8677 & 3.7531 \\
\hline APP & 98 & 97 & 127 & 83 & 95 & 112 & 117 & 91 & 98 & 88 & 101 & 127 & 83 & 98 \\
\hline ITR & 10.3093 & 10.3124 & 10.7147 & 9.6880 & 10.0196 & 10.4275 & 9.8337 & 9.3569 & 9.6876 & 9.4569 & 9.9807 & 10.7147 & 9.3569 & 9.9266 \\
\hline
\end{tabular}

Table I. Annual Profitability, Debt, Liquidity, Working Capital and Efficiency Ratios of the community pharmacy for the years $2003-2012$ ACP $=$ Average Collection Period; APP $=$ Average Payment Period; APTR = Accounts Payable Turnover Ratio; ARTR = Accounts Receivable Turnover Ratio; $C R$ = Current Ratio; DER = Debt to Equity Ratio; GPMR = Gross Profit Margin Ratio; ITR = Inventory Turnover Ratio; NPMR = Net Profit Margin Ratio; QR = Quick Ratio; WC = Working Capital as Percentage of Sales

\section{NPMR analysis}

From 2010 NPMR, as well as GPMR, has recorded a significant downward trend. Declining trend culminated in 2012 when has been recorded the lowest value of NPMR in comparison to the values achieved during the whole examined decade $(\mathrm{min}=0.0229 / 2.29 \%$; $\max =0.1830 / 18.3 \%$; average $=14.62 \%$; mean $=16.62 \% ; \sigma=4.92)$. It reflects an alarming condition for the independent community pharmacy. It primarily shows that community pharmacy is not generating enough sales and additionally that its gross profit margin is relatively low. Furthermore, it denotes that the business is unable to keep operating expenses under control so as to leave an acceptable profit. The community pharmacy is almost generating no profit for its operations, condition that might indicate the need to take on debt to pay its expenses.

\section{Corrective action in NPMR}

In order to survive from this alarming downtrend of NPMR, community pharmacy should reduce fixed and variable costs. Decreasing payroll expenses should be an essential and vital remedial effort. Payroll expenses include all wages and salaries, employee taxes and generally all benefits for all staff of the business including owners. Moreover, it should also decrease all other operating expenses, frequently referred to as overhead. These expenses include advertising, insurance, store supplies, containers and labels, delivery expenses, office postage, computer expenses, rent, utilities and telephone. Additionally, it should decrea- se cost of goods sold (COGS) and revise pricing so as to achieve higher gross profit margins. It should proceed to certain efficiency improvements such as increasing the use of technology through investing in labor-saving technologies. Besides, enterprise should look over obtaining revenue for medication therapy management services provided.

\section{Debt ratio}

\section{DER analysis}

The estimated DER for the examined independent community pharmacy was mostly lying between the acceptable range of $1: 1$ and 4:1. DER recorded on $2012\left(\mathrm{x}_{2012}=2.33\right)$ was almost equal to the recommended one which is $2: 1(\min =2.33$; $\max =4.81$; average $=3.44$; mean $=3.07 ; \sigma=0.82$ ).

\section{Corrective action in DER}

Although DER is generally lying between acceptable ranges, a more careful managing of the inventory purchased and a better controlling of current liabilities may stabilize DER to the recommended value. In such way, business's vulnerability to risk will be decreased and ensured its viability so as to continue its future operations.

\section{Liquidity ratios}

\section{CR analysis}

During the given decade, community pharmacy's CR was laying between acceptable ranges. The declining trend from 2006 and the relatively low value recorded on 2012 
signifies a worrying tendency for the $\mathrm{CR}$ $(\min =1.13 ; \max =1.71 ;$ average $=1.43$; mean $=1.46 ; \sigma=0.15$ ). If community pharmacy's CR continues its declining trend, it may eventually lead to a condition in which insufficient current assets will not be available to meet short term financial obligations.

\section{Corrective action in CR}

Therefore, community pharmacy should primarily perform investment in current assets and then try to manage and control better its current liabilities. In this way, CR of the enterprise will gradually record a positive trend and get more close to the desired value of $2: 1$. As a result, community pharmacy's business will be empowered with higher capacity to meet its short term financial obligations.

\section{QR analysis}

During the given decade $\mathrm{QR}$ was generally lying between acceptable ranges. The lowest value recorded during 2012 signifies a worrying tendency for the $\mathrm{QR}(\mathrm{min}=0.72$; $\max =1.27$; average $=1.07$; mean $=1.09$; $\sigma=0.15)$. It indicates that without the need to sell inventory, the business so not able to meet its short term liabilities.

\section{Corrective action in QR}

The community pharmacy should primarily perform investment in current assets and then try to manage and control better its current liabilities. Consequently, community pharmacy's business will be empowered with higher capacity to meet its short term liabilities from current assets without the need to sell inventory.

\section{Working Capital and Working Capital Ratio}

\section{WCR analysis}

By comparing the WCR from one period to another, we can conclude that the final value of WCR, as recorded on $2012\left(\mathrm{x}_{2012}=2.66\right)$ signifies a short WC cycle and a remarkable increase in the effectiveness of business's WC $($ WCR $\min =2.66 ; \max =12.94$; average $=9.58 ;$ mean $=10.06 ; \sigma=3.1)$. Therefore, it is obvious that during 2012 has been realized an improvement to the overall WC cycle of the enterprise since it needed less money to fund its normal, day to day operations and moreover became able to achieve a faster collection of money.

\section{Efficiency ratios}

\section{ARTR analysis}

During the examined decade, most problematic were the periods of 2005 and 2008-09. The business was performing an insufficient management of debtors or it had less liquid debtors. The community pharmacy reassessed its credit management procedures and from 2010 and then it has achieved faster collection of debts. The best value recorded in $2012\left(\mathrm{x}_{2012}=6.75\right)$ with the shortest time needed between the sale and collecting the cash for that sale $(\min =3.22 ; \max =6.75$; average $=4.38$; mean $=4.31$ ). Furthermore, this value denotes that receivables are efficiently managed, fewer resources are invested in receivables and generally better credit and collection practices are in place.

\section{ACP analysis}

The most problematic were the periods of 2005 and 2008-2009 with the longest average collection periods. During those years, it has been observed a significant influence in the cash flow of the business since its money was tied up in customer credit for longer time intervals. Through reassessing its credit management procedures, community pharmacy achieved to overcome its liquidity issues. The 54 days average collection period recorded on 2012 signified that receivables have been managed more efficiently than previous years with fewer resources invested in them $(\min =54 ; \max =113$; average $=87$; mean $=85)$.

\section{APTR analysis}

The higher is the APTR, the better. During the examined decade, most problematic were the periods of 2005, 2008 and 2009. The business was inefficiently handling its outgoing payments. The community pharmacy reassessed its credit purchases and from 2010 and then it has achieved faster payments of its suppliers. The best value recorded in 2012 $\left(\mathrm{x}_{2012}=4.16\right)$ with the fastest rate between purchasing inventory or materials and paying for them and denotes that business is managing more efficiently its outgoing payments $(\min =2.87 ; \max =4.39 ;$ average $=3.69$; mean $=3.75$ ).

\section{APP analysis}

During the years 2005, 2008 and 2009 there have been recorded the longest APP $(\min =83$; $\max =127$; average $=101$; mean $=98)$. Although those periods were indicative that the business was experienced problems with cash shortages, on another point of view, they may also be indicative of a good business's cash management. The numbers of days recorded during the other seven years of the examined decade were characterized by a slightly faster rate in the payment of business's suppliers. This slightly faster rate reflects the creditworthiness of the community pharmacy to its suppliers but also denotes that business is partially taking advantage of the credit terms allowed by suppliers. 


\section{ITR analysis}

During the given decade examined community pharmacy's business experienced its best ITR during 2005 and $2008(\mathrm{~min}=9.36$; $\max =10.71$; average $=9.98 ;$ mean $=9.93)$. A high ITR usually means that pharmacy managers are using inventory more efficiently. ITR achieved during those years indicate that business was purchasing new inventory items to replace the inventory having actually being sold and that fewer inventory items were sitting idle on the shelves. Furthermore, less cash was tied up in inventory and it eventually was available for other uses, such as increasing profitability. During 2010 and 2012 have been recorded the lowest values of the ITR $\left(x_{2010}=9.36\right.$ and $\left.x_{2012}=9.46\right)$ which indicated that business was carrying out too much inventory. Possible reasons for this fact might include deterioration, damage, obsolescence or overestimation of the community pharmacy's needs. These low ITR may also be indicative of a naturally slow moving inventory in the industry.

\section{Annual number of customers}

Table II provides an overview of the annual amount of customers who visited the pharmacy and the approximate average amount of patients who visited the pharmacy each single day of every examined fiscal year.

From 2009 up to 2012, it has been observed an accelerated declining trend to the annual and daily amount of patients who visited the pharmacy. This condition obviously reflects the deep impact of the financial crisis to the pharmacy practice. The dramatically decreased number of customers during the last four years explains the problematic ability of the business to generate profit. The accelerated changes in the financial and economic profile of the country led people to minimize their visits to the pharmacy and become more conservative in their expenses for pharmaceutical goods or services [22].

During the period of recession, serious socio-economic changes occurred. Salaries of employees, pensions and other benefits that before crisis were handed out in reasonable levels have been reduced dramatically [23]. This condition resulted in a noticeable decre- ase in the ability of consumers to purchase products intended both for health and cosmetic aspects [24]. In specific, it has been observed a significant change in the habits and behavior of consumers, guiding them to decrease their spontaneous purchases, postponing possible purchases and generally decrease their total purchases [25]. Furthermore, the priorities of customers in buying products have been switched over, to either choosing the cheapest form or not buying anything at all, even at the cost of their own health [26]. This situation caused a serious decrease in the income of the pharmacy and posed limitations on the ability of pharmacists to ensure financial stability for their businesses.

\section{CONCLUSION}

Evaluation of community pharmacy operations and overall performing is essential at the time of financial crisis, recession and serious socio-economic changes. The financial statements analysis seems to be the convenient method for developing an overall community pharmacy business assessment. The described approach towards the evaluation of community pharmacy business relies on monitoring indicators of financial analysis. The more comprehensive and detailed the analysis, the better will be the financial development of the community pharmacy. Through improved management and healthier controlling of the business finances, pharmacy managers will be able to make more informed decisions regarding the appropriate allocation of resources as well as the overall business direction. Financial analysis will essentially help managers to identify trends or problems along with improved interventions to ameliorate problems and plan for the future. The final result of financial statements analysis will be an obvious improvement of community pharmacy's efficiency and prosperity accompanied with a positive and profitable economic development. By conducting a thorough financial analysis, pharmacy managers will guarantee a more effective and viable position for their businesses among other competitors in the market.

\begin{tabular}{|c|c|c|c|c|c|c|c|c|c|c|c|c|c|c|}
\hline & \multicolumn{10}{|c|}{ Year } & \multicolumn{4}{|c|}{ 2003-2012 } \\
\hline & 2003 & 2004 & 2005 & 2006 & 2007 & 2008 & 2009 & 2010 & 2011 & 2012 & Average & Max & Min & Mean \\
\hline N. of cust/year & 27,240 & 25,548 & 31,284 & 29,492 & 29,500 & 29,885 & 23,305 & 20,810 & 18,619 & 15,099 & 25,078 & 29,885 & 15,099 & 26,394 \\
\hline $\begin{array}{l}\text { Average } n \text {. of } \\
\text { cust/wd }\end{array}$ & 101 & 95 & 116 & 109 & 109 & 111 & 86 & 77 & 69 & 56 & 93 & 111 & 56 & 98 \\
\hline
\end{tabular}

Table II. Number of customers who visited the community pharmacy from 2003-2012

cust = customers; wd = working day 


\section{REFERENCES}

1. Cheng Y, Raisch DW, Borrego ME, et al. Economic, clinical and humanistic outcomes (ECHOs) of pharmaceutical care services for minority patients: A literature review. Res Social Adm Pharm 2013; 9: 311-29; http://dx.doi. org/10.1016/j.sapharm.2012.05.004

2. Ifanti AA, Argyriou AA, Kalofonou FH, et al. Financial crisis and austerity measures in Greece: Their impact on health promotion policies and public health care. Health Policy 2013; 113: 8-12; http://dx.doi.org/10.1016/j. healthpol.2013.05.017

3. Goranitis I, Siskou O, Liaropoulos L. Health policy making under information constraints: An evaluation of the policy responses to the economic crisis in Greece. Health Policy 2014; 117: 279-84; http://dx.doi.org/10.1016/j. healthpol.2014.07.012

4. Markovits Y, Boer D, van Dick R. Economic crisis and the employee: The effects of economic crisis on employee job satisfaction, commitment, and self-regulation. European Management Journal 2014; 32: 413-22; http://dx.doi. org/10.1016/j.emj.2013.09.005

5. Vogler S, Habimana K, Art D. Does deregulation in community pharmacy impact accessibility of medicines, quality of pharmacy services and costs? Evidence from nine European countries. Health Policy 2014; 117: 311-27; http:// dx.doi.org/10.1016/j.healthpol.2014.06.001

6. Jacobs S, Schafheutle EI, Jee SD, et al. Existing arrangements for monitoring community pharmacies in England: Can they have a role in the revalidation of pharmacists? Res Social Adm Pharm 2013; 9: 166-77; http://dx.doi. org/10.1016/j.sapharm.2012.07.006

7. Bush J, Langley CA, Wilson KA. The corporatization of community pharmacy: Implications for service provision, the public health function, and pharmacy's claims to professional status in the United Kingdom. Res Social Adm Pharm 2009; 5: 305-18; http://dx.doi.org/10.1016/j.sapharm.2009.01.003

8. McMillan SS, Wheeler AJ, Sav A, et al. Community pharmacy in Australia: A health hub destination of the future. Res Social Adm Pharm 2013; 9: 863-75; http://dx.doi.org/10.1016/j.sapharm.2012.11.003

9. Norris P, Horsburgh S, Sides G, et al. Geographical access to community pharmacies in New Zealand. Health Place 2014; 29: 140-5; http://dx.doi.org/10.1016/j.healthplace.2014.07.005

10. Keast SL, Jacobs E, Harrison D, et al. Future economic outlook of Nebraska rural community pharmacies based on break-even analysis of community operational costs and county population. Res Social Adm Pharm 2010; 6: 209-20; http://dx.doi.org/10.1016/j.sapharm.2009.07.003

11. Perepelkin J, Dobson RT. Influence of ownership type on role orientation, role affinity, and role conflict among community pharmacy managers and owners in Canada. Res Social Adm Pharm 2010; 6: 280-92; http://dx.doi. org/10.1016/j.sapharm.2009.11.001

12. Carroll NC, Miederhoff PA, Waters LW. Profitability, third-party reimbursement, and access to community pharmacies. Clin Ther 1996; 8: 703-15; http://dx.doi.org/10.1016/S0149-2918(96)80221-9

13. Herist N, Rollins B, Perri M. Financial Analysis in Pharmacy Practice. London: Pharmaceutical Press, 2011

14. Annemans N. Health Economics for Non-Economists: An Introduction to the Concepts, Methods and Pitfalls of Health Economic Evaluations. Gent: Academia Press, 2008

15. Doucette WR, McDonough RP, Mormann MM, et al. Three-year financial analysis of pharmacy services at an independent community pharmacy. J Am Pharm Assoc (2003) 2012; 52: 181-7; http://dx.doi.org/10.1331/JAPhA.2012.11207

16. Moullin J, Sabater-Hernández D, Fernandez-Llimos F, et al. Defining professional pharmacy services in community pharmacy. Res Social Adm Pharm 2013; 9: 989-95;

17. http://dx.doi.org/10.1016/j.sapharm.2013.05.012

18. Schroeder R, Clarc M, Cathey JM. Financial Accounting Theory and Analysis. New Jersey: John Wiley \& Sons, 2011

19. Chrisholm-Burns MA, Vaillancrt AM, Shepherd M. Pharmacy Management, Leadership, Marketing and finance. Sudbury: Jones and Barlett Publishers, 2011

20. Tootilian BH, Wertheimer AI, Mikhailitchenko A. Essentials of Pharmacy Management. London: Pharmaceutical Press, 2012

21. Aparasu RR. Research Methods for Pharmaceutical Practice and Policy. London: Pharmaceutical Press, 2011

22. Radford A, Mason M, Richardson I, et al. Continuing effects of Medicare Part D on rural independent pharmacies who are the sole retail provider in their community. Res Social Adm Pharm 2009; 5: 17-30; http://dx.doi. org/10.1016/j.sapharm.2008.04.004 
23. Sánchez-Serrano I. The World's Health Care Crisis. The United States' Leadership. The World's Health Care Crisis, London: Elsevier 2011

24. Matsaganis M. The Greek Crisis: Social Impact and Policy Responses. Department of Western Europe/North America, Berlin, 2013.

25. Söderberg IL, Wester M. Lay actions in the face of crisis-Swedish citizens' actions in response to the global financial crisis of 2008. The Journal of Socio-Economics 2012; 41 : 796-805; http://dx.doi.org/10.1016/j.socec.2012.08.007

26. de Belvis AG, Ferrè F, Specchia MC, et al. The financial crisis in Italy: Implications for the health care sector. Health Policy 2012, 106: 10-6; http://dx.doi.org/10.1016/j.healthpol.2012.04.003

27. Ásgeirsdóttir TL, Corman H, Noonan K, et al. Was the economic crisis of 2008 good for Icelanders? Impact on health behaviors. Econ Hum Biol 2014; 13: 1-19; http://dx.doi. org/10.1016/j.ehb.2013.03.005 